\title{
A Narrative Literature Review Addressing the Relationship between Students Enrollment and Campus-Based Financial Aid in United State of America
}

\author{
Babatunde A. Akinbobola \\ Department of Public Administration \\ Nelson Mandela College of Government and Social Sciences \\ Southern University and A \& M College
}

\begin{abstract}
This article utilizes narrative literature review method to examine the impactful effect of financial aid on students' enrolment in general. As part of the narrative literature review analysis a Boolean search of 50 articles met the criteria for inclusion. In relation to the literature search, the data collection procedure considered the first and second authors of the completed simultaneous electronic and ancestral searches for peer-reviewed articles by using the following online databases: APA-PsycINFO, Education Research Complete (ERC), Education Resources Information Center (ERIC), Education Index, Education Full Text, Crossref, IndexCopernicus, and SPORTDiscus as well as Google scholar and advanced Google scholar. As part of the findings for the study utilized for the article, many scholars made specific inferences to the campus-based financial aid in their studies as the main fiscal management determinants of students' enrollment. Out of the fifty articles, 25 of the researchers, thus $50 \%$, underscored and also perceived fiscal management as a determinant of students' enrolment by utilizing the concept of campus-based financial aid availability or tuition waiver. Researchers of 25 articles-thus $50 \%$-- explicitly stated that participants had difficulty connecting financial aid availability with students' enrolment. A total of 13 (25\%) researchers have explained in their research that student' and management teams were able to make the connection between financial aid availability and students' enrolment (or choice of school). Above all, the article has unearthed implications as well as made cogent suggestion for future research in order to contribute to overall educational policy of society.
\end{abstract}

Keywords: Students' enrolment, financial aid, fiscal management, tuition cost, realist, idealist, HBCU, and education.

DOI: $10.7176 / \mathrm{JEP} / 12-34-02$

Publication date: December $31^{\text {st }} 2021$

\section{INTRODUCTION}

Educationist and policymakers have been concerned about the unequal access to higher education across demographic groups, coupled with the general population's overall level of educational attainment. Additionally, as part of the major concern of the unequal access to education, many citizens of United States of American have devoted a significant portion of their attention to college access. The primary concern was that the exorbitant price of college education had excluded many people, who are from disadvantaged backgrounds. As part of the challenge of policymakers and government officials to administrators in higher education, officialdom held transparent opinions that public and institutional policies should, as a result, endeavor to correct the foregoing problem by subsidizing students and assisting in bringing prices within their reach. Additionally, it was revealed that about 19 million individuals borrowed a total of 90 billion dollars in 2010 alone for the sole purpose of pursuing college education due to the resultant benefit such education provides to the general population (U. S. Department of Education, 2010). Baum (2007) also stated how the benefits of collegiate education go well beyond the financial incentive to the individual seeking either education or an academic degree. As several experts have confirmed, collegiate education impacts society through increased civic involvement as well as the lowering of crime and incarceration rates, and in lowering unemployment rates.

Meanwhile, it has also been shown that financial assistance is available to qualified applicants in pursuit of higher education at the federal, the state, and the local levels. According to U. S. Department of Education (2010), the primary sources of federal aid, which are available to students in Louisiana at public two-year institutions as well as the Higher education, are the Pell Grant and student loans. Then, as a result of the limited financial aid sources as well as unavailability on campuses, enrollment managers have been prompted to serve as very active and retroactive participants in the financial-aid process and the practice of leveraging financial aid in order to enroll and retain students. This is because, as college costs continue to rise against relatively stagnant household incomes, the pressure on institutions to provide a lot more financial aid from their operating budgets has also grown. However, it is not clear whether enrolment mangers find it ideal the real relationship between students' enrolment and financial aid availability within an institution.

Meanwhile, it is also a fact that if an institution succeeds in winning desirable applicants from peer institutions 
with the offer of g non-need-based aid, the peer institutions are not likely tolerating the situation. They will, as a result, offer competitive packages and, indeed, it is very easy to see how competition for these students can lead to a price war, thus depleting institutional funds without bringing any more qualified and well-prepared students into the applicant pool. Everyone, in the process, will lose in the long run, with the exception that the obvious lucky students, who could have paid full price, but who now enjoy lower net prices than even students from the lowest income families. Then the students, without the ability to pay, will simply drop out of the pool, and collectively the institutions will not be able to improve the quality of the students they enroll.

Indeed, addressing this state of affairs is important because it is quite unfortunate that little is known about what relationship exist between the financial aid and student's enrollment, whether it has a short-term relationship or a long-term relationship in order to have the opportunity to better inform education policy makers as well as enrollment managers. As a result of the unknown relationship, many campuses only focus on the leveraging of financial-aid in order to have their incoming class (for the short-run), but fewer consider ongoing analysis to keep current students enrolled in the long-run. Instead, researchers have underscored in financial aid literature that before any institution decides to increase its tuition cost, for example, it must first examine the financial needs of all students in order to make necessary adjustments on the basis of the need-based awards of incoming students to ensure that enrollment met the stated institutional goals (Hundrieser, 2015). Also, numerous studies have demonstrated that it is cheaper to keep an enrolled student in place than it is to recruit a new one (Hundrieser, 2015).

Consequently, it is obvious that either such a focus or the above study in general is very significant mainly because it will enable readers, scholars, school officials and administrators as well as members of Board of Directors and institutional leaders to find answers to such under-listed relational and managerial questions as follows: (a) Is the institution spending too much on financial aid? Is it being spent on the right students? (b) What is the balance between net revenue and the discount rate? How do our financial-aid strategy and policies reflect our institutional values? (c) Do we use aid appropriately to assist with student persistence and retention? And (d) Should students, who are achieving high levels of academic success, be rewarded and encouraged to remain enrolled with additional scholarships? In fact, underscoring the idealistic or the realistic relationship between the students' enrollment and campus-based financial aid will assist in the development and improvement of financialaid strategy, which is an important component of attracting and retaining the students the institution seeks to serve.

Also, by making the connections and linking the relationships between the two variables from the different perspectives of scholars, this concept explicates the false narrative of the achievement gap by highlighting on how financial aid impacts enrolment in higher education of Historically Black Colleges and Universities (HBCUs). Then, given the foregoing realities and testimonies from the various scholars and the need for addressing the literature gap, the goal of this particular article is to conduct a narrative literature review to understand better the relationship between students' enrolment and campus-based financial aid. To further explain to readers in a plain sense, the study specifically seeks to answer the researched question below: How have researchers in higher education, enrollment management, and financial aid departments addressed the relational concepts for both Students' enrollments and financial aids availability?

Unfortunately, it is very obvious that HBCU institutions are more likely to be constrained with financial aid availability than the non-HBCUs. Indeed, it is an undeniable fact HBCUs have been suffering from low enrollment rates as compared to the non-HBCUs colleges or institutions. Therefore, for the purposes of this article and illustrations, HBCUs will be conceptualize as a model case to be used in the study since they are surrounded by impoverished students, lack of adequate learning materials, low staffing, and low students' enrolment as well as less availability of financial aids and grants for potential students. Campuses should include financial aid in the student success and completion conversation and evaluate financial-aid awards to make sure financially challenged students remain enrolled.

\section{LITERATURE REVIEW}

Given that students have choices in selecting higher educational institutions, and where they wish to study, enrollment management should establish, early on, a client relationship with their continuing students, parents and their target population (Answers.com, 2002; Seidman, 1995). Meanwhile, his aspect of the theoretical framework, therefore, argues that both students' perspectives and their needs should always be either paramount or kept in the forefront when developing as well as offering services, launching new programs and initiatives, and evaluating enrollment management plans (Answers.com, 2002; Seidman, 1995).

In addition to marketing HBCUs of Higher Education programs, enrollment management should be concerned with creating the best learning and teaching environments for students. Therefore, the respective College needs to balance such factors as academic program development as well as faculty development, academic policy formulation, recruitment policies and procedures, student life programs, retention policies, and procedures (Answers.com, 2002; Seidman, 1995).

Furthermore, one way of increasing enrollments is to increase the number of prospective students, who 
usually come through referrals of others, they have a much higher yield rate than those that come from other types of referrals, such as mailing lists. Building an active referral network requires an information system able to record and track students. Other ways to increase referral of student include targeted high school guidance counselors as well as faculty, alumni and such other significant groups as churches and community organizations (Seidman, 1995). Public relations, which provide a positive image of the HBCUs in the State, can also increase the referral of student (Seidman, 1995).

Based on the researcher's goal and objective of understanding the relationship between the financial aid and student's enrollment, whether it has a short-term relationship or a long-term relationship in order to better inform education policy as well as enrollment managers, the study choose to analyze the articles found in this review using the Enrolment and Fiscal Management (EFM) tenets.

Within EFM, Delgado and Stefancic (2012) and Seidman (1995) explained how scholars, academia, and students' perspective could be classified into three basic categories: idealist, realist, or middle ground. As basic descriptors, idealists contend students' choice or school selection and enrolment are maintained in the educational setting through financial availability, low cost of tuition, preference, ranking of school, racism, and many others. This analogy of idealist battles the endemic nature of low students' enrolment at the individual (or student) level rather than policy or structural level (Kongolo, 2012; Hossler, Schmit, and Vesper, 1998). For example, some students and families automatically equate higher cost with higher quality, all other things being equal. Other potential college matriculants automatically exclude higher costing institutions because they believe they cannot afford them (i.e. the need for financial aid). They often do this without any knowledge of possible financial aid awards (Kongolo, 2012; Hossler, Schmit, and Vesper, 1998). Therefore, based on the idealist view, the difficult task for most institutions is to try to determine how most of the students and families in their markets react to price.

The word that is most is emphasized here because reactions will not be uniform among all potential students is idealism, especially since the idealist views or targets the individual (or student) level rather than policy or structural, group level (Kongolo, 2012; Hossler, Schmit, and Vesper, 1998). Due to the interaction effects between tuition costs and financial aid programs, it is possible for enrollment managers, in consultation with other senior campus administrators, to simulate several approaches to tuition costs and financial aid. Some private and public colleges maintain low costs and offer very little institutional financial aid. These institutions rely on low costs as the primary financial factor in helping achieve their enrollment goals (Kongolo, 2012; Hossler, Schmit, and Vesper, 1998).

Alternatively, realists acknowledge the importance of students' personal attitudes towards their respective choices or selections of school as part of financial resource available for them and racism, but contend financial aid supremacy to boost student enrolments is maintained systematically through systemic fiscal management. Realists work less on changing individual preferences and choices or perceptions but rather emphasizes more on structural changes (or reforms) or policies (or strategies) to boost students' enrollment. For example, some private and public institutions intentionally pursue high-tuition and high-aid strategies. Often referred to as the "Robin Hood" strategy, these institutions set higher tuition rates and then target campus-based scholarship programs toward students whom they seek to enroll (Chapman and Jackson, 1987; Tierney, 1980; Hossler, Schmit, and Vesper, 1998). The scholarships lower the net cost of attendance and, in the process, influence the matriculation decisions of students, who receive these offers (Chapman and Jackson, 1987; Tierney, 1980; Hossler, Schmit, and Vesper, 1998). As part of the solution, focus is usually placed on the effects of campus-based financial aid and tuition cost on student enrollment decisions. However, it is important to keep in mind that some colleges and universities use low tuition costs rather than financial aid to help manage their enrollments (Chapman and Jackson, 1987; Tierney, 1980; Hossler, Schmit, and Vesper, 1998).

Relative to the two arguments, it is believed that the realist enrolment management team might emphasize change occurring at the structural (or management) level within the education sector. For example, providing preservative management strategies (or policies) to manage and control students' enrolment based on campusbased financial availability. For example, such institutional characteristics as selectivity, reputation, and depth of applicant pool also influence how prospective students are influenced by campus-based financial aid programs (Kongolo, 2012). For example, an Ivy League college or institution, with a very deep applicant pool, does not necessarily have to offer as much financial aid to induce students to enroll as compared to a regional, less wellknown private college, with a smaller applicant pool might have to offer a lot of financial aid programs in order to entice students' (Kongolo, 2012; Hossler, Schmit, and Vesper, 1998). Towards this end, this is not to say idealists disdain social action or structural actions. Meanwhile, the idealists focus might be at the individual level- pushing for action to change individual beliefs rather than at a structural (or policy) level.

\section{Method}

The study follows a narrative reviews type of study. Narrative reviews are beneficial in providing conclusions for researchers who examine topics that do not have one optimal way of measuring outcomes (Baumeister, 2003). The narrative nature of this review allowed the researcher to examine and describe a wide range of outcomes of research 
designed to address the relationship between students' enrolment and financial aid availability within higher education across United States of America. The selection of articles was based on the definition of students' enrolment, fiscal management, financial aid, tuition cost, and grants availability. Additionally, the researcher used the following criteria to select articles for the purposes of the review: (a) Study content included a focus on students' enrolment of higher education. Studies focusing on other types of enrolment management strategies without relying on financial aids. (b) Study content included also focus on campus-based financial aids, fiscal management, tuition cost, and grants available on campuses within the higher education settings. Studies focusing on other types of enrolment management strategies without relying on financial aids. (c) Researcher reported findings from empirical research designs (i.e. qualitative, quantitative, survey, or mixed methods designs). (d) All enrolment and financial aid related articles published in peer-reviewed journals. (e) Published books, book chapters, dissertations, and theoretical manuscripts were excluded based on the lack of peer-review in such publications.

As part of the literature search, the data collection procedure considered the first and second authors of the completed simultaneous electronic and ancestral searches for peer-reviewed articles by using the following online databases: APA-PsycINFO, Education Research Complete (ERC), Education Resources Information Center (ERIC), Education Index, Education Full Text, Crossref, IndexCopernicus, and SPORTDiscus as well as Google scholar and advanced Google scholar.

In fact, by using the Boolean indicators, "or", "and" and "not" the following search terms were entered into databases, students' enrolment, higher education enrolment strategies, financial aids, campus-based financial aid, fiscal management, campus-based grants, tuition cost, prospective students, students' choice, students' preferences for school selections, campus-based enrolment management aims, and financial aid availability for students. It is important to note that the initial search results yielded about 10,524 relevant articles across all the search engines. Based on the large number of authors using the terms "student enrolment" and "financial aid" in numerous ways, an abstract filter was also applied to the selection criteria. The study further widens the scope of the search to minimize the sampling of the selected articles by focusing on the specific relationships between students' enrolment and financial aid availability for college or university students. This particular search yielded about 500 articles through the help of abstract filters. After the abstract filtration to reduce the size of the articles' selections, the researcher uses the two concepts, "student enrolment" and "financial aid availability" to determine whether those remain articles meet the inclusion criteria, and 50 articles were chosen for inclusion.

\section{Data Analysis}

For the article, both deductive and inductive coding of the concepts were used for the search. These concepts included financial aid availability, low cost of tuition, students' preference, enrollment decisions, ranking of school, racism, and many others. In relation to the experts' views and readings of the 50 articles, deductive codes were developed but were later observed to be insufficient in capturing all the concepts relevant to the estimation of the results or the findings. In view of the gap in estimation, the researcher further develops an inductive coding to strengthen the analysis. The researcher used counter-stories to operationalize the relationship between student enrolment and financial aid.

Generally, it is difficult to understand why financial aid has become such an important part of enrollment management efforts without summarizing the research on the impact of financial aid on prospective college students and enrolled college students. However, research in this area has increased significantly in recent years in the context of higher educational systems in general. According to available data, the system in the United States of America is diverse as well as complicated in student enrolment competitions. Generally, five (5) research teams Heller, 1997; Jackson, 1978; Leslie and Brinkman, 1987; St. John, 1990) have provided a detailed discussion of how campus-based financial aid policies affect students' decisions of considering individual institutions. In particular, how students considering a regional private comprehensive college might respond to campus-based financial aid programs should be quite different from how those applying to a public doctoral-granting flagship university may respond. Also, students who plan to live at home to attend a commuter campus have a price threshold that is very different from students considering rural residential institutions (see Table 1 for more details). 
Table 1: Characteristics of Identified Studies and Variables

\begin{tabular}{|c|c|c|}
\hline Characteristics of Identified Studies and Variables & Percentage $(\%)$ & Number $(n)$ \\
\hline Difficulty connecting financial aid availability with students' enrolment & 50 & 25 \\
\hline Ability to connect financial aid availability and students' enrolment & 25 & 13 \\
\hline Goals of connecting financial aid availability and students' enrolment & 8 & 4 \\
\hline $\begin{array}{l}\text { Goals of understanding financial aid availability and students' } \\
\text { enrolment }\end{array}$ & 8 & 4 \\
\hline Connecting America's diversity and student enrolment competitions & 4 & 2 \\
\hline \multicolumn{3}{|l|}{ Enrolment and Financial Assistance } \\
\hline Campus based financial aid/Tuition Waiver & 50 & 25 \\
\hline Student loans & 50 & 25 \\
\hline Scholarship & 25 & 13 \\
\hline Assistantship & 5 & 3 \\
\hline Work-study & 25 & 13 \\
\hline Students grants & 5 & 3 \\
\hline \multicolumn{3}{|l|}{ Realist Descriptors } \\
\hline social or institutional activism & 60 & 30 \\
\hline $\begin{array}{l}\text { References to management strategies, or policies, or institutional } \\
\text { structures of financial aid availability for enrolment decisions }\end{array}$ & 48 & 24 \\
\hline \multicolumn{3}{|l|}{ Idealist Descriptors } \\
\hline Low cost of tuition & 25 & 13 \\
\hline Financial aid availability & 48 & 24 \\
\hline Students' preference & 25 & 13 \\
\hline Students' choice for high ranked schools & 48 & 24 \\
\hline Racism & 12 & 6 \\
\hline \multicolumn{3}{|l|}{ Realist Implications } \\
\hline Social action & 24 & 12 \\
\hline Federal or political or legislative action & 4 & 2 \\
\hline Management action [learning and teaching environments] & 12 & 6 \\
\hline Enrollment committee action & 12 & 6 \\
\hline Institutional action or characteristics of selectivity & 4 & 2 \\
\hline \multicolumn{3}{|l|}{ Idealist Implications } \\
\hline End racism & 8 & 4 \\
\hline Understanding school rankings & 4 & 2 \\
\hline Understanding campus-based financial aid prospects and accessibility & 40 & 20 \\
\hline Understanding tuition cost waiver & 36 & 18 \\
\hline
\end{tabular}

Note: Fifty total articles.

Researchers of $25(50 \%)$ articles explicitly stated participants had difficulty connecting financial aid availability with students' enrolment. Thirteen (25\%) researchers (Heller, 1997; Jackson, 1978; Leslie and Brinkman, 1987; St. John, 1990; Chapman and Jackson, 1987; Kongolo, 2012; Coomes, 2000; University Business, 2006; Quirk, 2005; Thomas and Perna, 2004; Hossler, Braxton, and Coopersmith, 1989; Paulsen, 1990; Leslie and Brinkman, 1987) explained in their research that student' and management teams were able to make the connection between financial aid availability and students' enrolment (or choice of school). These thirteen authors further explained the goals of connecting financial aid availability to students' enrolment of higher education in order to inform educational policy. Additionally, four (8\%) other research teams (Coomes, 2000; University Business, 2006; Quirk, 2005; Thomas and Perna, 2004) vividly stated the goals and relevance of connecting or linking campus-based financial aid availability to students' enrolments. Above all, two (4\%) researchers (Hossler, Braxton, and Coopersmith, 1989; Paulsen, 1990) arguably connected the odds of student enrolment competitions to the different racial groups or diversity nature of American's population.

\section{Idealist Perspectives of the Narrative Review}

To examine the idealistic impacts of financial aid on the college enrollment decisions of traditional- age students, it is helpful to draw from two strands of research, which include meta-analyses of the effects of financial aid on student enrollment decisions and also research on the college choice process as discussed in the theoretical framework of the entire research. Therefore, several reviews and meta-analyses of the effects of financial aid on enrollment decisions are available (Heller, 1997; Jackson, 1978; Leslie and Brinkman, 1987; St. John, 1990). Each of them reaches similar conclusions. One key finding, however, is that receiving a financial aid award has a 
significant positive effect on the likelihood that a student will enter the institution that has made the financial aid offer (Heller, 1997; Jackson, 1978; Leslie and Brinkman, 1987; St. John, 1990). Indeed, such reviews conclude that the effect of just receiving an award, regardless of the amount, equals or exceeds the effects of the amount of the award. This conclusion is not meant to infer that the amount of a campus-based award does not influence college matriculation decisions. However, the amount of an aid offer generally does matter (Heller, 1997; Jackson, 1978; Leslie and Brinkman, 1987; St. John, 1990).

Several studies have also demonstrated that enrollment decisions are influenced by the amount of financial aid awards (Chapman and Jackson, 1987; Tierney, 1980). For emphasis, however, it should be noted that the effects of aid interact in complex ways. Students may turn down a generous financial aid package from a small regional private college if they are admitted to a prestigious Ivy League college that offers no financial aid.

Furthermore, it is difficult to separate the impact of tuition on student enrollments from the effects of student financial aid. Tuition cost, too, is clearly a signaling device for prospective students and parents. The problem, however, is that effects of tuition costs and financial aid do not uniformly affect the decisions of prospective or currently- enrolled college students. Some students and families automatically equate higher cost with higher quality, all other things being equal. Other potential college matriculants automatically exclude higher costing institutions because they believe they cannot afford them (i.e. the need for financial aid). They often do this without any knowledge of possible financial aid awards (Kongolo, 2012; Hossler, Schmit, and Vesper, 1998).

Furthermore, researches have s consistently found that African American students and Latino students are more cost sensitive and more responsive to financial aid offers than majority students of similar socio-economic background (Hossler, Braxton, and Coopersmith, 1989; Paulsen, 1990). In a similar fashion, it typically requires larger scholarships to influence the enrollment decisions of high-ability students. These students are heavily recruited by many colleges and universities and are often offered many large scholarships. These students are also more likely to be interested in institutions with higher levels of prestige and greater selectivity. For these reasons, many colleges and universities need to offer higher-ability students larger scholarship awards if they wish to influence their enrollment decision on the basis of financial aid offers (Chapman and Jackson, 1987).

More so, it is important to note that the growing competition for college students of all ability levels, but especially the competition for high ability students, has resulted in greater amounts of campus general fund money being invested in scholarships designed to influence the enrollment decisions of students. Hence, it is possible that students have become even more responsive or elastic to the amount of their financial aid awards. In a recent book, titled "Going to College: How Social, Financial, Educational Experiences Influence the Decisions Students Make" (by Hossler, Schmit, and Vesper, 1998), it is shown that the effects of how perceived costs, financial aid, and other factors influence the college enrollment decisions of high school students as they move from the ninth grade through high school graduation; that has been carefully researched by the authors, who found that one of the primary factors that parents, and later students, consider when dropping or adding colleges to the list of schools they are considering is the perceived costs and the probabilities of receiving financial aid. This process of either dropping or adding schools starts as early as the tenth grade.

Additionally, parents play a key role in this process. Simple statements such as "We can't afford to send you to that school" or "You can attend that school if you get a scholarship" can have a powerful impact on which institutions students seriously consider. These findings are consistent with Jackson's meta-analysis of the effects of financial aid on student enrollment decisions. Jackson (1978) concluded that many students fail to consider or needlessly eliminate colleges and universities that might have been good choices for them because they believe they cannot afford to attend these schools. These findings lead to two additional conclusions. Total cost of attendance also influences the decisions of students long before they get to the point of selecting which college to attend. As a result, the timing of when students (and their parents) learn about actual or possible financial aid packages can influence the planning for going to college, even at very early stages of the process.

In all 50 articles were used for the study discussion. The articles revealed the idealist implications (see Figure 1 and Table 1 for more details). 


\section{Idealist Implications [50 Articles]}

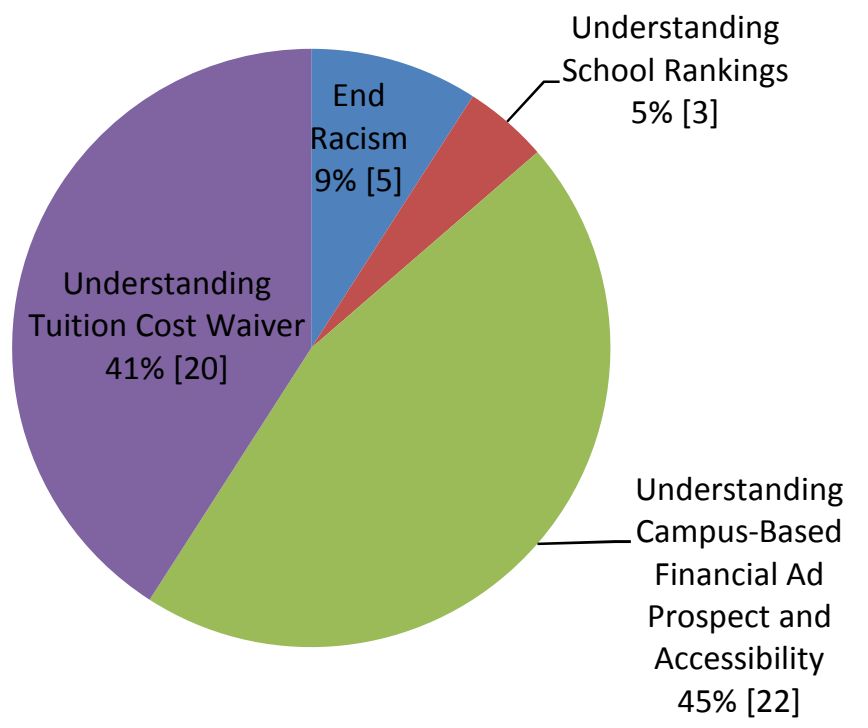

\section{Figure 1: Idealist Implications}

Source: Author's modification

\section{Realist Perspectives of the Narrative Review}

The realistic perspective of this particular analysis focused on the afore-mentioned realist descriptors (see table 1 for more details). The realist descriptors of social or institutional activism are considered and selected or referenced whenever the researcher or author uses the concepts of management strategies, or policies, or institutional structures of financial aid availability. For the case of realist implications, they are coded whenever the authors use or propose a social action or policies or management action or policies in their study to facilitate and/or improve students' enrolment.

As part of the realist analysis, it is observed that institutional characteristics such as selectivity, reputation, and depth of applicant pool also influence how prospective students are influenced by campus-based financial aid programs. The difficult task for most institutions is to try to determine how most of the students and families in their markets react to price. The word most is emphasized here because reactions will not be uniform among all potential students. Due to the interaction effects between tuition costs and financial aid programs, it is possible for enrollment managers, in consultation with other senior campus administrators, to simulate several approaches to tuition costs and financial aid. Some private and public colleges maintain low costs and offer very little institutional financial aid. These institutions rely on low costs as the primary financial factor in helping achieve their enrollment goals (Kongolo, 2012; Hossler, Schmit, and Vesper, 1998).

The most widely discussed campus-based response to the effects of financial aid on the college decisions of students in the context of the current financial pressures placed on institutions, students, and families is some variant of the Robin Hood strategy. This approach raises tuition and uses large portions of the increase to provide financial aid to prospective college students in order to induce them to matriculate. Although these financial aid inducements might be used to meet student financial need, the intent behind the strategy is to use the award as a merit award that will help individual campuses more effectively recruit students with higher grades, with more talent, or with lower levels of financial need. In the admissions and financial aid community there is a great deal of discussion of financial aid leveraging.

Meanwhile, aid leveraging is an analytical tool that enables admissions and financial aid administrators to estimate the amount of financial aid (regardless of formal need formulas) that would be necessary to increase the probability that a student with a specified set of characteristics would enroll. The usual characteristics often include variables such as academic performance, socioeconomic status, major, ethnicity, place of residence, and special talents. It must be remembered, however, that this approach is not without increased costs. It is a fact that institutions have to increase their tuition, increase the education and general portion of the budget that is allocated to financial aid, or both to induce talented students' recruitment. The increased focus on ratios between tuition income and financial aid expenditures has changed the discussion on many campuses.

In the early 1970s and even among private institutions, it was uncommon to have more than 10 to 15 percent of total tuition revenue returned in the form of scholarships or discounts to students (Hossler, 1984). Currently, it 
is not uncommon for private institutions to have discount rates as high as 25 to 30 percent. Institutional policymakers often become more concerned about net tuition revenue than total student enrollment (Hossler, 1984). Originally, Robin Hood strategies were used by private sector institutions. Nevertheless, public institutions have also started to use this technique to optimize revenues (Hossler, 1984).

Public flagship institutions, however, face difficult problems with this approach for their out-of-state student markets. If they continue to raise their tuition, they run the risk of reaching tuition levels that come close to the costs of more selective private institutions (Hossler, 1984; Edgerton, 1993). Most of these private colleges and universities award significant amounts of student financial aid. These large scholarships and increased competition for high-ability students make it increasingly difficult for public flagships to recruit out-of-state students without investing even more in their financial aid programs (Hossler, 1984; Edgerton, 1993). It is unlikely that tuition leveraging can continue indefinitely. The costs of competing, over the size of tuition discounts, will eventually cause cost increases that go beyond what students are willing to pay (Edgerton, 1993).

Again, Des Jardins, Ahlburg, and McCall (2002) included campus-based financial aid as one measure in their examination of the effects students' enrolment. Using data from the University of Minnesota, they found that campus-based scholarships and grants increased the likelihood of student persistence. Above all, Martin (2004) provides a thoughtful analysis and critique of the uses and misuses of campus-based financial aid on external measures of institutional quality, of total undergraduate enrollment, and of the fiscal health of colleges and universities. A number of other studies have considered the effects of financial aid on enrollment decisions (see, e.g., DesJardins, Ahlburg, \& McCall, 1999; Hossler, Hu, \& Schmit, 1999; Hu \& Hossler, 2000; McPherson, Schapiro, \& Winston, 1993). Singell and colleagues (2002a, 2002b, 2002c) have also published a number of studies that focus exclusively on the effects of institutional aid on student enrollment behaviors.

In all 50 articles discussed the realist implication (see Figure 2 for more details).

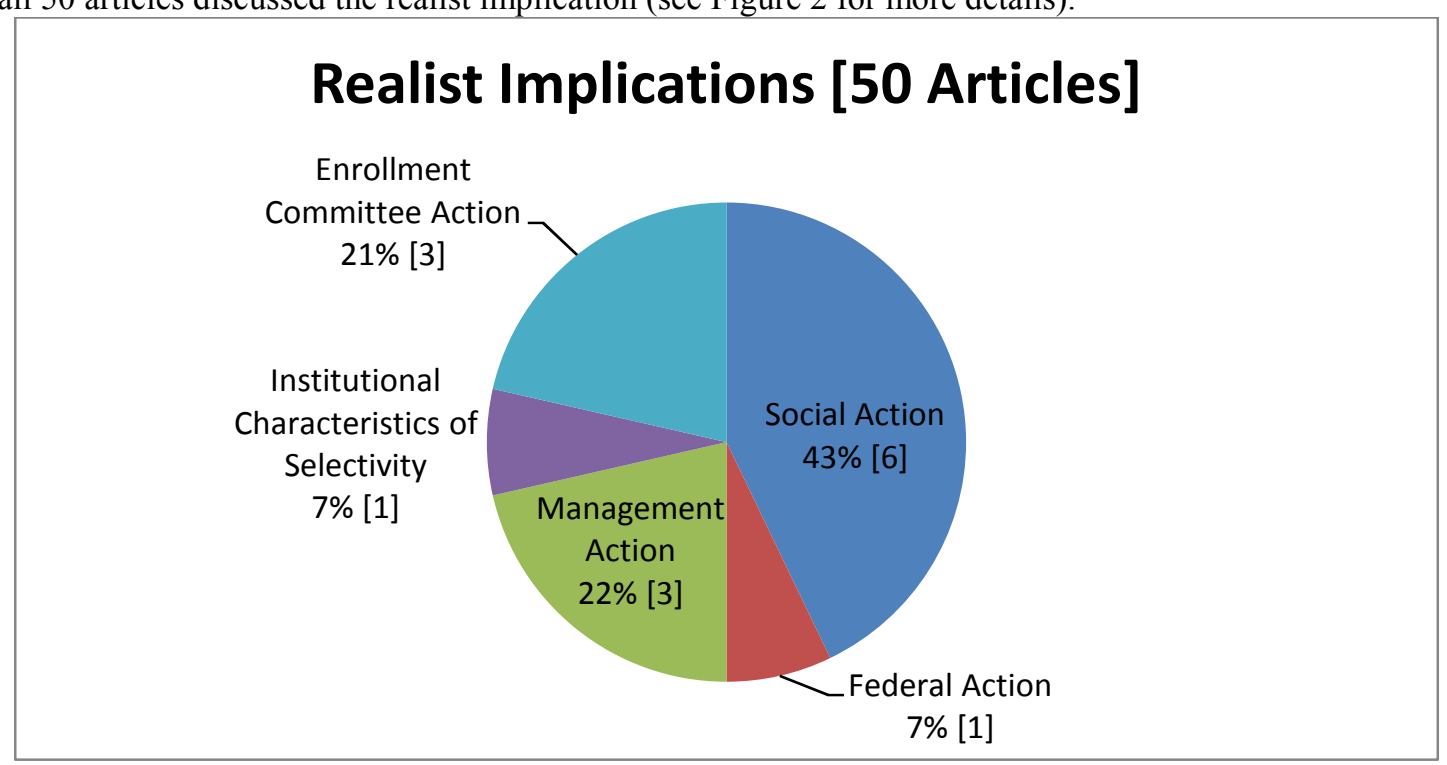

Figure 2: Realist Implications

Source: Author's modification

\section{Conclusion: Discussion and Implications}

Toward the foregoing end, many of the researchers' findings indicate that colleges and universities can use campus-based financial aid to help them achieve their enrollment goals $(n=46,92 \%)$. It was also observed from the numerous reviews $(n=38,75 \%)$ that financial aid awards, along with tuition costs, may exert a strong influence on the number and types of prospective students that consider attending individual colleges and universities. Above all, the cumulative results of these studies $(n=50,100 \%)$ indicate that colleges and universities should continue to emphasize that campus-based aid, even modest awards, may have a positive impact on the matriculation decisions of prospective students. However, it is also difficult to separate the impact of tuition on student enrollments from the effects of student financial aid. Perhaps, it was underscored in the numerous literature $(n=21,42 \%)$ that tuition cost is clearly a signaling device for students and parents.

Nevertheless, it still not very clear whether or not there exists a causal relationship between tuition cost and student enrolment as well as financial aid and students' enrolment in minority schools, particularly HBCUs. Therefore, in order to fill the literature gap, it is highly recommended that a granger causality analysis should be conducted with empirically- based available data to demonstrate whether or not enrolment causes high cost of tuition or tuition cost causes low enrolment of student by a particular institution. 


\section{References}

Answers.com (2002). Enrollment Management in Higher Education. Retrieved 28 November 2011 from: http://www.answers.com/topic/enrollment-management-in-highereducation.

Baum S, Payea K (2004). Education pays 2004: The benefits of higher education for individuals and society. Washington, DC: The College Board.

Bennett, S. J.; Driver, K.M.; and Trent, C. S. (2017). Real or Ideal? A narrative literature Review Addressing White Privilege in Teacher Education. Thousand Oaks, California: Sage Publication.

Chapman, R. C., and Jackson, R. (1987). College Choices of Academically Able Students: The Influence of NoNeed Financial Aid and Other Factors. Research Monograph No. 10. New York: College Board.

Coomes, M. (2000). The Role Financial Aid Plays in Enrollment Management. San Francisco: Jossey-Bass.

DesJardins, S. L., Ahlburg, D. A., \& McCall, B. P. (2002). Simulating the longitudinal effects of changes in financial aid on student departure from college. Journal of Human Resources, 37(3), 653-679.

Edgerton, R. (1993). "The Public Scrutiny of the Value of Higher Education.” AAHE Bulletin, 1993, 45 (10), 3-7.

Heller, D. (1997). "Student Price Response in Higher Education: An Update to Leslie and Brinkman." Journal of Higher Education, 1997, 56, 735-750.

Hossler, D. (1984). Enrollment Management: An Integrated Approach. New York: College Board.

Hossler, D., and Bean, J. P. (1990). The Strategic Management of College Enrollments. San Francisco: JosseyBass.

Hossler D. (1985). Enrollment management: A paradigm for student affairs professionals. NASPA J., 23(2): p. 2 8.

Hossler D. (1984). Enrollment management: An integrated approach. New York: College Board.

Hossler D, and John, P. (1990). The Strategic Management of College Enrollments. San Francisco: Jossey-Bass.

Hossler, D., Braxton, J., and Coopersmith, G. (1989). “Understanding Student College Choice.” In J. Smart (ed.), Higher Education: Handbook of Theory and Research. Vol. 4. New York: Agathon, 1989.

Hossler, D., Schmit, J., and Vesper, N. (1998). Going to College: How Social, Economic, and Educational Factors Influence the Decisions Students Make. Baltimore: Johns Hopkins University Press.

Hossler, D., Hu, S., and Schmit, J. (1999). Predicting student sensitivity to tuition and financial aid. Journal of Student Financial Aid, 28(4), 17-33.

Hundrieser J. (2011). Four risks that admissions directors must manage with recruitment materials and social media. Retrieved 4 November 2011, from: http://blog.noellevitz.com/2011/09/13/riskmanagementadmissions-part-1-recruitment-materials-technology/.

Hundrieser, J. (2015). From What Board Members Need to Know about Enrollment Management, AGB Press.

Interstudy News. (2011). The University of the Western Cape. Retrieved 7 November 2011 from:http://www.interstudy.org/universities/20university-of-the-western-cape.

Jackson, G. A. (1978). "Financial Aid and Student Enrollment." Journal of Higher Education, 49, 1978, 548-574

Jantzen, J. (1991). Enrollment management: The model, the manager and the message. J. Market. High. Educ., 3(2): 129-139.

Kongolo, M. (2012). Enrolment Management: The perspectives of university of the Western Cape, South Africa. African Journal of Business Management, Vol.6 (24).

Leslie, L. L., and Brinkman, P. T. (1987)."Student Price-Response in Higher Education." Journal of Higher Education, 1987, 58, 181-204.

Lichtman, M. (2013). Qualitative research in education: a user's guide ( $3^{\text {rd }}$ edition). Thousand Oaks, California: Sage Publications.

Lieblich, A.; Tuval-Mashiach, R.; and Ziber, T. (1998). Narrative Research reading, analysis, and interpretation. Thousand Oaks, California: Sage Publications. Vol. 47.

Martin, R. E. (2004). Tuition discounting without tears. Economics of Education Review.23, 177-189.

McPherson, M. S., Schapiro, M. O., and Winston, G. C. (1993). Paying the piper: Productivity, incentives, and financing in U.S. higher education. Ann Arbor, MI: University of Michigan Press.

Quirk, M. (2005). The Best Class Money Can Buy. The AtlanticMagazine, November. Retrieved on 6 Nov. 2011 from http://byliner.com/matthew-quirk/stories/the-best-class-money-canbuy.

Seidman, A. (1995). Parkland College Enrollment Management Model. Champaign, IL. (ERIC Document Reproduction Service No.ED 384 375). Center for the Study of College Student Retention. Retrieved 7 Nov. 2011 from: http://www.cscsr.org/article enrollment management.htm

Singell, L. D., Jr. (2002a). Merit, need, and student self-selection: Is there discretion on the packaging of aid at a large public university? Economics of Education Review, 21, 445-454.

Singell, L. D., Jr., and Curs, B. R. (2002b). An analysis of the application process and enrollment demand for instate and out-of-state students at a large public university. Economics of Education Review, 21, 111-124.

Singell, L. D., Jr., and Stone, J. A. (2002c). The good, the poor and the wealthy: Who responds most to college financial aid? Bulletin of Economic Research, 54(4), 393-407. 
St. John, E. P. (1990). "Price Response in Enrollment Decisions: An Analysis of High School and Beyond Sophomore Cohort." Research in Higher Education, 1990, 31, 161-176.

Thomas, S.L., and Perna, L.W. (2004). The opportunity agenda: A reexamination of postsecondary reward and opportunity. In Smart JC (Ed.), Higher education: Handbook of theory and research, Vol. 19. Dordrecht, The Netherlands: Kluwer Academic Publishers.

Tierney, M. L. (1980). "Student Matriculation Decisions and Financial Aid." Review of Higher Education, 1980, 3 (2), 14-25.

University Business. (2006). White Paper: Connecting Enrollment and Fiscal Management. Solution for Higher Education Management. Retrieved on 5 November 2011, from: http://www.universitybusiness.com/article/white-paper-connectingenrollment-and-fiscal-management 